FACTA UNIVERSITATIS

Series: Working and Living Environmental Protection Vol. 18, № 1, 2021, pp. 11 - 25

https://doi.org/10.22190/FUWLEP2101011L

Review Paper

\title{
POTENTIAL HEALTH IMPACT OF DRINKING WATER SOURCES: CASE STUDY FROM SERBIA
}

\author{
UDC 628.16.033(497.11)
}

\section{Vesna Lazarević ${ }^{1}$, Miodrag Đorđević ${ }^{\text {, Nataša Đorđević }}{ }^{3}$, Nikola Igić ${ }^{4}$, Ana Stojković5, Ivan Krstić5}

${ }^{1}$ Center for Preventive Medical Care in Niš, Military Hospital Niš, Serbia

${ }^{2}$ University of Nis, Faculty of Sciences and Mathematics, Department of Mathematics, Serbia

${ }^{3}$ University of Nis, Faculty of Sciences and Mathematics, Department of Chemistry, Serbia

${ }^{4}$ Kvalitet a.d. Niš, Serbia

${ }^{5}$ University of Niš, Faculty of Occupational Safety, Serbia

\begin{abstract}
Drinking water quality has a direct impact on the health of the population and is the main indicator of environmental sanitation and hygienic living conditions. The aim of this study was to investigate the quality of drinking water from three water supply systems in Serbia.

The retrospective descriptive study was done covering the period between 2011 and 2015. We collected data from control water supply systems in three towns and tested the samples as required by the Regulation on the Hygienic Acceptability of Potable Water. The following indicators of water security were analyzed: ammonia, nitrates, nitrites, consumption of potassium permanganate, organic matter content, $\mathrm{pH}$ and electroconductivity. The microbiological quality was determined by analyzing the indicators of fecal contamination, Escherichia coli, Enterococci and Salmonellae, using the membrane filtration method.

The most frequent parameters of physical-chemical insecurity of water were a high concentration of ammonia, lower $\mathrm{pH}$ levels, and increased consumption of potassium permanganate. The most common detected microbes were aerobic mesophilic bacteria which are not significant from the aspect of human health.

These results showed that drinking water could pose a potential risk to local consumers.
\end{abstract}

Key words: drinking water, quality, health aspect.

Received April 12, 2021 / Accepted April 21, 2021

Corresponding author: Ana Stojković

University of Niš, Faculty of Occupational Safety, Čarnojevića 10a, 18000 Niš, Serbia

E-mail: ana.stojkovic@znrfak.ni.ac.rs 


\section{INTRODUCTION}

Drinking water quality has a direct impact on the health of the population and is the main indicator of environmental sanitation and hygienic living conditions [1].

Water quality control is carried out according to the program in compliance with the Regulation on Hygienic Safety of Drinking Water [2]. Laboratory analyses of water samples are performed according to the Regulation on Sampling and Laboratory Methods for the Analysis of Drinking Water [3], implying physical-chemical and microbiological water quality. Drinking water quality control is performed in many water supply systems. Taking into consideration the specificity of preparation and drinking water treatment, as well as the results of a longitudinal examination of water quality, the reference systems chosen were public water supply systems in the city of Nis, the town of Krusevac and the town of Vranje. In the framework of a systematic analysis of drinking water quality, the sampling was carried out at defined locations.

The methodological approach to assessing the qualitative impact of drinking water on health using a descriptive risk indicator of drinking water quality and its corresponding percentage of incorrectness is shown in Table 1 [4].

Table 1 Risk indicators of drinking water quality in terms of microbiological, physicalchemical incorrectness

\begin{tabular}{ccccc}
\hline Level & $\begin{array}{c}\text { Microbiological } \\
\text { incorrectness, } \%\end{array}$ & Description & $\begin{array}{c}\text { Physical-chemical } \\
\text { incorrectness, } \%\end{array}$ & Description \\
\hline 1 & $<2$ & Insignificant & $<5$ & Acceptable \\
2 & $2.1-5$ & Small & $5.1-10$ & Partially acceptable \\
3 & $5.1-10$ & Moderate & $10.1-20$ & Bad \\
4 & $10.1-25$ & Large & $20.1-50$ & Very bad \\
5 & $>25$ & Huge & $>50$ & Alarming \\
\hline
\end{tabular}

In terms of health, a special place can be given to the physical-chemical and microbiological properties of water that may have various negative implications. The presence of nitrogen compounds (ammonia, nitrates, nitrites) above the maximum permissible concentration (MPC) indicates potential microbial incorrectness, whereas the increased consumption of $\mathrm{KMnO}_{4}$ indicates the presence of organic compounds in water that are of anthropogenic, vegetable or animal origin.

The most common health risk is unsafe drinking water caused directly or indirectly by the excretion of microorganisms found in human and animal feces. Typical waterborne diseases are caused by microorganisms from the gastrointestinal tract of humans and domestic animals when waste materials penetrate groundwater sources of drinking water. Fecal contamination of drinking water leads to dispersion of pathogenic bacteria, which can cause disease in the whole community that uses drinking water from the same water supply system. However, a potentially pathogenic organism shall not always cause symptomatic disease in all persons it comes in contact with. It depends on several factors: the concentration of pathogens in water, strain virulence, infective dose of a given pathogenic microorganism, susceptibility of individuals, and the incidence of infection in the community [5]. Therefore, the microbiological analysis of water is mainly based on the concept of fecal bacteria as indicators, while the presence of ammonia cannot be considered a reliable indicator for the preliminary screening of emergency outbreaks caused by fecal contamination [6]. 
The coliform group has been used extensively as an indicator of water quality and has historically led to the public health protection concept [7].

Based on recent legislation, the bacteria $E$. coli is the most suitable indicator of the possible presence of pathogenic microorganisms caused by fecal contamination [8]. Also, Ashbolt and colleagues found that the monitoring of the presence of $E$. coli in water, as the most specific indicator of fresh fecal contamination, directly indicates a risk to human health [9].

Recent research has found that, although they do not meet all the criteria for an ideal indicator, non-pathogenic strains of E. coli are considered as a potential indicator of fecal contamination of drinking water [10].

Enterococcus (fecal streptococcus) is another group of bacteria present in the feces of humans and animals. In comparison to E. coli, Enterococcus is not found in a great number in human feces, but it survives in water for a longer period of time, and therefore is considered a better indicator of the presence of fecal contamination of water [5]. Enterococcus is a genus with numerous species, but E. faecalis and E. faecium are dominant species that cause infections in humans and are important indicators of fecal contamination of drinking water [11].

The aim of the article is to present the results and health aspect of physical-chemical and microbiological quality of drinking water from the control water supply systems in Krusevac, Nis and Vranje in the 2011-2015 period, as well as health impact assessment of risk indicators of drinking water quality in terms of microbiological, physical-chemical incorrectness, in the above mentioned period.

\section{METHODS}

The analytical method in the form of a retrospective descriptive study, covering the period from 2011 to 2015 was applied. Statistical analysis and the presentation of the results were performed using the software packages Excel, SPSS 19.0 and XLSTAT2020 (Addinsoft, 2020). The following statistical methods were used for data analysis: descriptive statistics (arithmetic mean and standard deviation, frequency, percentage) to determine the extent of the basic variables in the research; correlation technique to determine the orientation and the correlation between the variables, analysis of variance (One-way ANOVA) with Post hoc LSD test included to determine the significance of differences between the mean concentrations of drinking water quality parameters in three towns, and principal component (PCA) and agglomerative hierarchical analyses (AHC) [12].

\section{RESULTS}

The analysis of physical-chemical parameters of drinking water $\left(\mathrm{C}_{\mathrm{NH} 4+}, \mathrm{C}_{\mathrm{NO} 3-}, \mathrm{C}_{\mathrm{NO} 2-}\right.$, $\mathrm{C}_{\mathrm{KMnO}}, \mathrm{pH}$ and conductivity) in the reference water supply systems was executed based on the results of chemical analysis of characteristic parameters and maximum permissible concentrations which are indicators of drinking water quality, as well as using descriptive statistics and analysis of variance (One-way ANOVA) in the period between 2011 and 2015 are shown in Tables 2-6. 
Table 2 Descriptive statistics and results of ANOVA tests in 2011

\begin{tabular}{|c|c|c|c|c|c|c|c|c|c|}
\hline $\begin{array}{l}\text { The measured } \\
\text { parameter }\end{array}$ & $\begin{array}{c}\text { Water supply } \\
\text { system }\end{array}$ & $\mathrm{N}$ & $\mathrm{AD}$ & SD & Min & Max & $\mathrm{F}$ & $\mathrm{p}$ & MPC \\
\hline \multirow{3}{*}{$\begin{array}{l}\mathrm{C}_{\mathrm{NH} 4^{+}} \\
\left(\mathrm{mg} \mathrm{dm}^{-3}\right)\end{array}$} & Kruševac & 106 & 0.00 & 0.00 & 0.00 & 0.00 & \multirow{3}{*}{84.92} & \multirow{3}{*}{0.000} & \multirow{3}{*}{0.10} \\
\hline & Niš & 113 & 0.00 & 0.00 & 0.00 & 0.00 & & & \\
\hline & Vranje & 112 & 0.09 & 0.10 & 0.00 & 0.60 & & & \\
\hline \multirow{3}{*}{$\begin{array}{l}\mathrm{C}_{\mathrm{NO}^{-}}^{-} \\
\left(\mathrm{mg} \mathrm{dm}^{-3}\right)\end{array}$} & Kruševac & 106 & 3.2 & 0.97 & 0.6 & 4.9 & \multirow{3}{*}{194.41} & \multirow{3}{*}{0.000} & \multirow{3}{*}{50} \\
\hline & Niš & 113 & 3.3 & 1.56 & 1.4 & 7.2 & & & \\
\hline & Vranje & 112 & 0.8 & 0.38 & 0.1 & 1.9 & & & \\
\hline \multirow{3}{*}{$\begin{array}{l}\mathrm{C}_{\mathrm{KMnO} 4} \\
\left(\mathrm{mg} \mathrm{dm}^{-3}\right)\end{array}$} & Kruševac & 106 & 8.28 & 2.77 & 2.22 & 12.66 & \multirow{3}{*}{60.88} & \multirow{3}{*}{0.000} & \multirow{3}{*}{8.5} \\
\hline & Niš & 113 & 5.23 & 1.96 & 2.07 & 12.64 & & & \\
\hline & Vranje & 112 & 7.77 & 1.81 & 3.79 & 13.34 & & & \\
\hline \multirow{3}{*}{$\mathrm{pH}$} & Kruševac & 106 & 7.5 & 0.24 & 6.8 & 8.1 & \multirow{3}{*}{62.32} & \multirow{3}{*}{0.000} & \multirow{3}{*}{$6.8-8.5$} \\
\hline & Niš & 113 & 7.6 & 0.37 & 6.6 & 8.3 & & & \\
\hline & Vranje & 112 & 7.1 & 0.38 & 6.2 & 7.8 & & & \\
\hline \multirow{3}{*}{$\begin{array}{l}\text { Electrical } \\
\text { conductivity } \\
\left(\mu \mathrm{S} \mathrm{cm}^{-1}\right)\end{array}$} & Kruševac & 106 & 329 & 29.46 & 256 & 391 & \multirow{3}{*}{2088.56} & \multirow{3}{*}{0.000} & \multirow{3}{*}{1000} \\
\hline & Niš & 113 & 426 & 46.83 & 347 & 618 & & & \\
\hline & Vranje & 112 & 148 & 11.60 & 126 & 185 & & & \\
\hline
\end{tabular}

Table 3 Descriptive statistics and results of ANOVA tests in 2012

\begin{tabular}{|c|c|c|c|c|c|c|c|c|c|}
\hline $\begin{array}{l}\text { The measured } \\
\text { parameter }\end{array}$ & $\begin{array}{c}\text { Water supply } \\
\text { system }\end{array}$ & $\mathrm{N}$ & $\mathrm{AD}$ & SD & Min & Max & $\mathrm{F}$ & $\mathrm{p}$ & MPC \\
\hline \multirow{3}{*}{$\begin{array}{l}\mathrm{NH}^{+} \\
\left(\mathrm{mg} \mathrm{dm}^{-3}\right)\end{array}$} & Kruševac & 113 & 0.00 & 0.00 & 0.00 & 0.00 & \multirow{3}{*}{187.23} & \multirow{3}{*}{0.000} & \multirow{3}{*}{0.10} \\
\hline & Niš & 113 & 0.00 & 0.00 & 0.00 & 0.00 & & & \\
\hline & Vranje & 110 & 0.07 & 0.05 & 0.00 & 0.19 & & & \\
\hline \multirow{3}{*}{$\begin{array}{l}\mathrm{C}_{\mathrm{NO}^{-}}^{-} \\
\left(\mathrm{mg} \mathrm{dm}^{-3}\right)\end{array}$} & Kruševac & 113 & 4.04 & 1.17 & 1.80 & 6.90 & \multirow{3}{*}{298.88} & \multirow{3}{*}{0.000} & \multirow{3}{*}{50} \\
\hline & Niš & 113 & 3.70 & 1.64 & 0.40 & 8.20 & & & \\
\hline & Vranje & 110 & 0.53 & 0.33 & 0.10 & 1.60 & & & \\
\hline \multirow{3}{*}{$\begin{array}{l}\mathrm{C}_{\mathrm{KMnO} 4} \\
\left(\mathrm{mg} \mathrm{dm}^{-3}\right)\end{array}$} & Kruševac & 113 & 7.62 & 1.13 & 3.95 & 12.87 & \multirow{3}{*}{38.30} & \multirow{3}{*}{0.000} & \multirow{3}{*}{8.5} \\
\hline & Niš & 113 & 5.02 & 1.48 & 2.49 & 10.06 & & & \\
\hline & Vranje & 110 & 7.54 & 4.00 & 3.02 & 31.16 & & & \\
\hline \multirow{3}{*}{$\mathrm{pH}$} & Kruševac & 113 & 7.2 & 0.33 & 6.4 & 8.0 & \multirow{3}{*}{228.86} & \multirow{3}{*}{0.000} & \multirow{3}{*}{$6.8-8.5$} \\
\hline & Niš & 113 & 7.7 & 0.27 & 6.9 & 8.3 & & & \\
\hline & Vranje & 110 & 6.7 & 0.42 & 5.7 & 7.6 & & & \\
\hline \multirow{3}{*}{$\begin{array}{l}\text { Electrical } \\
\text { conductivity } \\
\left(\mu \mathrm{S} \mathrm{cm}^{-1}\right)\end{array}$} & Kruševac & 113 & 299 & 23.20 & 222 & 376 & \multirow{3}{*}{1288.78} & \multirow{3}{*}{0.000} & \multirow{3}{*}{1000} \\
\hline & Niš & 113 & 427 & 63.59 & 289 & 586 & & & \\
\hline & Vranje & 110 & 154 & 15.63 & 96 & 181 & & & \\
\hline
\end{tabular}

$\mathrm{N}$ - the sample size; AS - mean; SD - standard deviation; Min - minimum value; Max - maximum value; $\mathrm{F}$ - a ratio of variances; MAC - maximum permissible concentration. 
Table 4 Descriptive statistics and results of ANOVA tests in 2013

\begin{tabular}{|c|c|c|c|c|c|c|c|c|c|}
\hline $\begin{array}{l}\text { The measured } \\
\text { parameter }\end{array}$ & $\begin{array}{l}\text { Water supply } \\
\text { system }\end{array}$ & $\mathrm{N}$ & $\mathrm{AD}$ & SD & Min & Max & $\mathrm{F}$ & $\mathrm{p}$ & MPC \\
\hline \multirow{3}{*}{$\begin{array}{l}\mathrm{C}_{\mathrm{NH} 4^{+}} \\
\left(\mathrm{mg} \mathrm{dm}^{-3}\right)\end{array}$} & Kruševac & 116 & 0.00 & 0.00 & 0.00 & 0.00 & \multirow{3}{*}{111.18} & \multirow{3}{*}{0.000} & \multirow{3}{*}{0.10} \\
\hline & Niš & 106 & 0.00 & 0.00 & 0.00 & 0.00 & & & \\
\hline & Vranje & 116 & 0.06 & 0.06 & 0.00 & 0.00 & & & \\
\hline \multirow{3}{*}{$\begin{array}{l}\mathrm{C}_{\mathrm{NO}^{-}}^{-} \\
\left(\mathrm{mg} \mathrm{dm}^{-3}\right)\end{array}$} & Kruševac & 116 & 3.9 & 1.1 & 1.8 & 6.1 & \multirow{3}{*}{104.18} & \multirow{3}{*}{0.000} & \multirow{3}{*}{50} \\
\hline & Niš & 106 & 3.9 & 3.0 & 0.5 & 15.4 & & & \\
\hline & Vranje & 116 & 0.9 & 0.4 & 0.3 & 1.8 & & & \\
\hline \multirow{3}{*}{$\begin{array}{l}\mathrm{C}_{\mathrm{KMnO} 4} \\
\left(\mathrm{mg} \mathrm{dm}^{-3}\right)\end{array}$} & Kruševac & 116 & 8.23 & 1.60 & 5.45 & 13.27 & \multirow{3}{*}{288.84} & \multirow{3}{*}{0.000} & \multirow{3}{*}{8.5} \\
\hline & Niš & 106 & 4.24 & 1.12 & 2.01 & 8.53 & & & \\
\hline & Vranje & 116 & 7.18 & 1.00 & 5.17 & 9.22 & & & \\
\hline \multirow{3}{*}{$\mathrm{pH}$} & Kruševac & 116 & 7.4 & 0.40 & 6.3 & 7.9 & \multirow{3}{*}{166.11} & \multirow{3}{*}{0.000} & \multirow{3}{*}{$6.8-8.5$} \\
\hline & Niš & 106 & 7.8 & 0.33 & 6.6 & 8.4 & & & \\
\hline & Vranje & 116 & 6.9 & 0.29 & 6.3 & 7.9 & & & \\
\hline \multirow{3}{*}{$\begin{array}{l}\text { Electrical } \\
\text { conductivity } \\
\left(\mu \mathrm{S} \mathrm{cm}^{-1}\right)\end{array}$} & Kruševac & 116 & 305 & 35.75 & 235 & 399 & \multirow{3}{*}{1357.99} & \multirow{3}{*}{0.000} & \multirow{3}{*}{1000} \\
\hline & Niš & 106 & 419 & 54.00 & 301 & 572 & & & \\
\hline & Vranje & 116 & 152 & 18.73 & 109 & 183 & & & \\
\hline
\end{tabular}

$\mathrm{N}$ - the sample size; AS - mean; SD - standard deviation; Min - minimum value; Max - maximum value; $\mathrm{F}$ - a ratio of variances; MAC - maximum permissible concentration.

Table 5 Descriptive statistics and results of ANOVA tests in 2014

\begin{tabular}{|c|c|c|c|c|c|c|c|c|c|}
\hline $\begin{array}{l}\text { The measured } \\
\text { parameter }\end{array}$ & $\begin{array}{l}\text { Water supply } \\
\text { system }\end{array}$ & $\mathrm{N}$ & $\mathrm{AD}$ & SD & Min & Max & $\mathrm{F}$ & $\mathrm{p}$ & MPC \\
\hline \multirow{3}{*}{$\begin{array}{l}\mathrm{C}_{\mathrm{NH} 4}{ }^{+} \\
\left(\mathrm{mg} \mathrm{dm}^{-3}\right)\end{array}$} & Kruševac & 117 & 0.00 & 0.00 & 0.00 & 0.00 & \multirow{3}{*}{100.56} & \multirow{3}{*}{0.000} & \multirow{3}{*}{0.10} \\
\hline & Niš & 118 & 0.00 & 0.00 & 0.00 & 0.00 & & & \\
\hline & Vranje & 117 & 0.07 & 0.08 & 0.00 & 0.31 & & & \\
\hline \multirow{3}{*}{$\begin{array}{l}\mathrm{C}_{\mathrm{NO} 3}^{-} \\
\left(\mathrm{mg} \mathrm{dm}^{-3}\right)\end{array}$} & Kruševac & 117 & 4.7 & 1.58 & 2.1 & 7.4 & \multirow{3}{*}{216.89} & \multirow{3}{*}{0.000} & \multirow{3}{*}{50} \\
\hline & Niš & 118 & 3.1 & 1.66 & 0.6 & 12.7 & & & \\
\hline & Vranje & 117 & 1.1 & 0.34 & 0.1 & 2.1 & & & \\
\hline \multirow{3}{*}{$\begin{array}{l}\mathrm{C}_{\mathrm{KMnO4}} \\
\left(\mathrm{mg} \mathrm{dm}^{-3}\right)\end{array}$} & Kruševac & 117 & 7.64 & 2.27 & 1.93 & 13.73 & \multirow{3}{*}{96.33} & \multirow{3}{*}{0.000} & \multirow{3}{*}{8.5} \\
\hline & Niš & 118 & 4.60 & 1.69 & 2.21 & 11.77 & & & \\
\hline & Vranje & 117 & 6.77 & 0.97 & 5.12 & 9.55 & & & \\
\hline \multirow{3}{*}{$\mathrm{pH}$} & Kruševac & 117 & 7.2 & 0.33 & 6.1 & 8.2 & \multirow{3}{*}{195.57} & \multirow{3}{*}{0.000} & \multirow{3}{*}{$6.8-8.5$} \\
\hline & Niš & 118 & 7.8 & 0.31 & 7.1 & 8.5 & & & \\
\hline & Vranje & 117 & 7.0 & 0.33 & 6.2 & 7.6 & & & \\
\hline \multirow{3}{*}{$\begin{array}{l}\text { Electrical } \\
\text { conductivity } \\
\left(\mu \mathrm{S} \mathrm{cm}^{-1}\right)\end{array}$} & Kruševac & 117 & 309 & 43.17 & 215 & 398 & \multirow{3}{*}{1545.08} & \multirow{3}{*}{0.000} & \multirow{3}{*}{1000} \\
\hline & $\mathrm{Niš}$ & 118 & 418 & 39.99 & 289 & 562 & & & \\
\hline & Vranje & 117 & 165 & 14.00 & 124 & 192 & & & \\
\hline
\end{tabular}

$\mathrm{N}$ - the sample size; AS - mean; SD - standard deviation; Min - minimum value; Max - maximum value; $\mathrm{F}$ - a ratio of variances; MAC - maximum permissible concentration. 
Table 6 Descriptive statistics and results of ANOVA tests in 2015

\begin{tabular}{|c|c|c|c|c|c|c|c|c|c|}
\hline $\begin{array}{l}\text { The measured } \\
\text { parameter }\end{array}$ & $\begin{array}{c}\text { Water supply } \\
\text { system }\end{array}$ & $\mathrm{N}$ & AS & SD & Min & Max & $\mathrm{F}$ & $\mathrm{p}$ & MPC \\
\hline \multirow{3}{*}{$\begin{array}{l}\mathrm{C}_{\mathrm{NH} 4}^{+} \\
\left(\mathrm{mg} \mathrm{dm}^{-3}\right)\end{array}$} & Kruševac & 118 & 0.00 & 0.00 & 0.00 & 0.00 & \multirow{3}{*}{97.36} & \multirow{3}{*}{0.000} & \multirow{3}{*}{0.10} \\
\hline & $\mathrm{Niš}$ & 120 & 0.00 & 0.00 & 0.00 & 0.00 & & & \\
\hline & Vranje & 115 & 0.07 & 0.08 & 0.00 & 0.50 & & & \\
\hline \multirow{3}{*}{$\begin{array}{l}\mathrm{CNO}^{-} \\
\left(\mathrm{mg} \mathrm{dm}^{-3}\right)\end{array}$} & Kruševac & 118 & 3.9 & 1.72 & 1.2 & 7.8 & \multirow{3}{*}{94.42} & \multirow{3}{*}{0.000} & \multirow{3}{*}{50} \\
\hline & Niš & 120 & 3.5 & 1.91 & 0.9 & 9.8 & & & \\
\hline & Vranje & 115 & 1.4 & 0.52 & 0.5 & 2.6 & & & \\
\hline \multirow{3}{*}{$\begin{array}{l}\mathrm{C}_{\mathrm{KMnO4}} \\
\left(\mathrm{mg} \mathrm{dm}^{-3}\right)\end{array}$} & Kruševac & 118 & 8.16 & 2.52 & 3.47 & 12.32 & \multirow{3}{*}{62.49} & \multirow{3}{*}{0.000} & \multirow{3}{*}{8.5} \\
\hline & Niš & 120 & 5.22 & 1.94 & 1.89 & 10.11 & & & \\
\hline & Vranje & 115 & 6.71 & 1.49 & 3.34 & 10.06 & & & \\
\hline \multirow{3}{*}{$\mathrm{pH}$} & Kruševac & 118 & 7.4 & 0.24 & 6.8 & 8.2 & \multirow{3}{*}{103.40} & \multirow{3}{*}{0.000} & \multirow{3}{*}{$6.8-8.5$} \\
\hline & Niš & 120 & 7.8 & 0.28 & $\begin{array}{l}0.0 \\
7.0\end{array}$ & 8.5 & & & \\
\hline & Vranje & 115 & 7.1 & 0.53 & 5.7 & 7.8 & & & \\
\hline \multirow{3}{*}{$\begin{array}{l}\text { Electrical } \\
\text { conductivity } \\
\left(\mu \mathrm{S} \mathrm{cm}^{-1}\right)\end{array}$} & Kruševac & 118 & 322 & 24.67 & 267 & 399 & \multirow{3}{*}{1713.74} & \multirow{3}{*}{0.000} & \multirow{3}{*}{1000} \\
\hline & $\mathrm{Niš}$ & 120 & 415 & 53.86 & 277 & 546 & & & \\
\hline & Vranje & 115 & 144 & 18.60 & 105 & 173 & & & \\
\hline
\end{tabular}

$\mathrm{N}$ - the sample size; AS - mean; SD - standard deviation; Min - minimum value; Max - maximum value; $\mathrm{F}$ - a ratio of variances; MAC - maximum permissible concentration.

Based on the significance of ANOVA tests, it can be concluded that there were significant differences between the analyzed water supply systems in all tested parameters, except for the concentration of $\mathrm{NO}_{2}^{-}$, whose presence was not noticed.

Substantial deviation of maximum concentration of $\mathrm{NH}_{4}{ }^{+}$in drinking water was found in the water supply system in Vranje and it ranged from 0.19 to $0.60 \mathrm{mg} \mathrm{dm}^{-3}$ in summer. The presence of $\mathrm{NH}_{4}{ }^{+}$in the analyzed samples of drinking water was not noticed in reference systems in Nis and Krusevac.

The increased concentrations of maximum values of $\mathrm{KMnO}_{4}$ consumption were discovered in all reference systems, and they ranged between 9.22 and $13.73 \mathrm{mg} \mathrm{dm}^{-3}$, with a significant deviation in the water supply system in Vranje, where the actual value was $31.16 \mathrm{mg} \mathrm{dm}^{-3}$.

Minimum $\mathrm{pH}$ values of drinking water in Vranje and Krusevac ranged from 5.7 to 6.3 , and from 6.1 to 6.4 , respectively, which was significantly below the limit values $\mathrm{pH}$ of drinking water samples in the reference system in Nis was within the permitted range.

\section{Principal component analysis (PCA)}

In the first step of statistical evaluation, the Kolmogorov-Smirnov test (the significance level $\alpha$ was 0.05 ) was used to determine the distribution concentration against each investigated variable. This test revealed the original dataset was normally distributed for all samples, except the concentration of ammonium ions, where values equal to zero were removed from further analysis. Grubb's test revealed no outliers.

Performed Principal Component Analysis (PCA) shows two Eigenvalues more than one (2.320 and 1.820) which should be according to Kaiser criterion be used for the examination of variances (Kaiser 1960) explaining $82.796 \%$ of the variability. The first component explained $46.4 \%$ of the variability and the second $36.396 \%$ of the variability.

To get a better insight into the latent structure of the data, the correlation matrix was rotated using Varimax orthogonal rotation with Kaiser optimization. The results after rotation are shown in Table 7. 
Table 7 Factor loadings after Varimax rotation

\begin{tabular}{lrrrr}
\hline & $\mathrm{D} 1$ & $\mathrm{D} 2$ & $\mathrm{D} 3$ & $\mathrm{D} 4$ \\
\hline $\mathrm{AS}_{\mathrm{NH} 4}$ & -0.164 & 0.394 & 0.904 & 0.004 \\
$\mathrm{AS}_{\mathrm{NO} 3}$ & 0.936 & 0.140 & -0.321 & -0.023 \\
$\mathrm{AS}_{\mathrm{KMNO4}}$ & -0.787 & 0.191 & 0.585 & 0.052 \\
$\mathrm{pH}$ & 0.901 & 0.399 & 0.162 & 0.048 \\
$\mathrm{EC}$ & -0.218 & -0.913 & -0.345 & -0.006 \\
\hline
\end{tabular}

The first factor explained the largest proportion of variance (47.641\%). Representatives of this factor were $\mathrm{AS}_{\mathrm{NO} 3}, \mathrm{pH}, \mathrm{AS}_{\mathrm{KMnO} 4}$ with the highest loading values, and $\mathrm{AS}_{\mathrm{NH} 4}$ and $\mathrm{EC}$ with relatively low loading values. Apart from $\mathrm{AS}_{\mathrm{NH} 4}, \mathrm{AS}_{\mathrm{KMnO} 4}$ and $\mathrm{EC}$, all investigated variables had positive loading values for this factor. The key variable of the second factor is EC, which is responsible for $24.079 \%$ of the total variance. In case of the third factor, which is responsible for $28.168 \%$ of the total variance, the key variable is $\mathrm{AS}_{\mathrm{NH} 4}$. In the first factor of the rotated PCA $\mathrm{AS}_{\mathrm{NH} 4}, \mathrm{AS}_{\mathrm{KMNO} 4}$ and $\mathrm{EC}$, and $\mathrm{AS}_{\mathrm{NO} 3}$ and $\mathrm{pH}$ were negatively correlated, which indicates that there is a strong correlation between $\mathrm{AS}_{\mathrm{NO} 3}$ and $\mathrm{pH}$, and $\mathrm{AS}_{\mathrm{KMNO4}}$ (i.e., if $\mathrm{AS}_{\mathrm{NO} 3}$ and $\mathrm{pH}$ are higher, the values of $\mathrm{AS}_{\mathrm{KMNO} 4}$ will be lower).

\section{Agglomerative hierarchical clustering (AHC)}

AHC of the standardized variables using the Ward method, as an amalgamation rule, and the squared Euclidean distance, as a measure of the proximity between the samples, was performed.

The dendrogram shows that all the samples could be grouped into two main clusters. Cluster I was formed by samples V1-V5 (V1-the sample from Vranje from 2011; V2-the sample from Vranje from 2012; V3-the sample from Vranje from 2013; V4-the sample from Vranje from 2014; V5-the sample from Vranje from 2015); cluster II was formed from two subclusters: 1) the first subcluster was formed from samples N1-N5 (N1-the sample from Nis from 2011; N2-the sample from Nis from 2012; N3-the sample from Nis from 2013; N4-the sample from Nis from 2014; N5-the sample from Nis from 2015); 2) the second subcluster consisted from samples K1K5 (K1-the sample from Krusevac

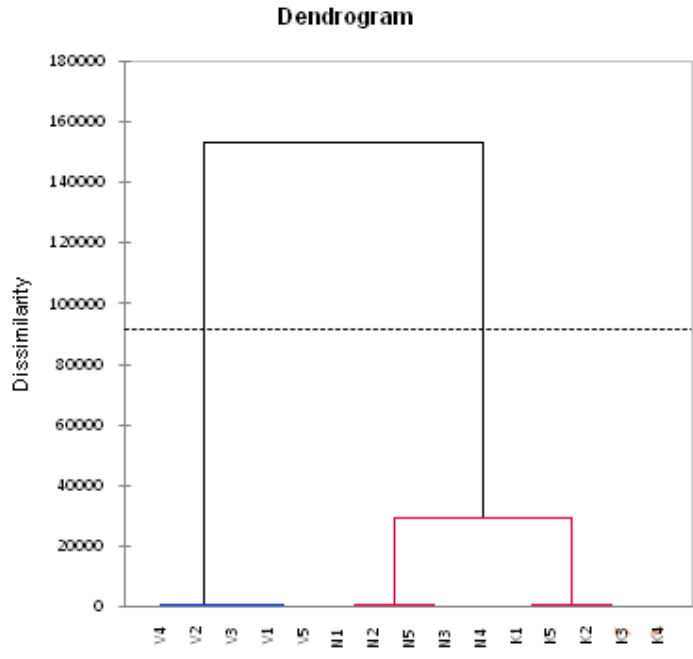

Fig. 1 Dendrogram presenting the clustering of water samples from 2011; K2-the sample from Krusevac from 2012; K3-the sample from Krusevac from 2013; K4-the sample from Krusevac from 2014; K5-the sample from Krusevac from 2015), figure 1. 


\section{Health safety of drinking water}

The health safety of drinking water in the reference water supply system in the examined period is shown in Table 8 .

Table 8 Health safety of drinking water samples (2011-2015)

\begin{tabular}{llrrr}
\hline Water supply system & $\begin{array}{c}\text { The total } \\
\text { number of } \\
\text { samples }\end{array}$ & $\begin{array}{c}\text { The total number } \\
\text { of safe samples } \\
\text { (microbiological, } \\
\text { physical-chemical) }\end{array}$ & $\begin{array}{c}\text { The total number } \\
\text { of unsafe samples } \\
\text { (mical-chemicalogical) }\end{array}$ \\
\hline Kruševac & Number of samples (\%) & $570(100 \%)$ & $312(54.74 \%)$ & $258(45.26 \%)$ \\
Niš & Number of samples $(\%)$ & $570(100 \%)$ & $529(92.81 \%)$ & $41(7.19 \%)$ \\
Vranje & Number of samples $(\%)$ & $570(100 \%)$ & $305(53.51 \%)$ & $265(46.49 \%)$ \\
\hline
\end{tabular}

The analyzed drinking water samples during the study period proved to be safe to human health (physical-chemical and microbiological safety) in 54.74\% (312), 92.81\% (529) and $53.51 \%$ (305) of controlled samples in water supply systems in Krusevac, Nis and Vranje, respectively. The causes of health unsafety were discovered in $45.26 \%$ (258), 7.19\% (41) and $46.49 \%$ (265) of controlled drinking water samples in the reference systems in Krusevac, Nis and Vranje, respectively. In comparison to the existing legal basis, physical-chemical incorrectness was found in $43.33 \%$ (247) of samples in Krusevac, 6.32\% (36) in Nis and $42.46 \%$ (242) in Vranje, whereas microbiological incorrectness was identified in $1.93 \%$ (11) of samples in Krusevac, $0.88 \%$ (5) in Nis and 4.03\% (23) in Vranje. Physical-chemical analysis of drinking water samples in the reference water supply systems in the study period is shown in Table 9.

Table 9 Physical-chemical analysis of drinking water samples (2011-2015)

\begin{tabular}{lcccc}
\hline Water supply system & $\begin{array}{c}\text { The total number } \\
\text { of } \\
\text { physical-chemical } \\
\text { samples }\end{array}$ & $\begin{array}{c}\text { The total number } \\
\text { of } \\
\text { physical-chemical } \\
\text { correct samples }\end{array}$ & $\begin{array}{c}\text { The total number } \\
\text { of } \\
\text { physical-chemical } \\
\text { incorrect samples }\end{array}$ \\
\hline Kruševac & Number of samples $(\%)$ & $570(100 \%)$ & $323(56.67 \%)$ & $247(43.33 \%)$ \\
Niš & Number of samples $(\%)$ & $570(100 \%)$ & $534(93.68 \%)$ & $36(6.32 \%)$ \\
Vranje & Number of samples (\%) & $570(100 \%)$ & $328(57.54 \%)$ & $242(42.46 \%)$ \\
\hline
\end{tabular}

Physical-chemical correctness of drinking water samples was identified in $56.67 \%$ (323), $93.68 \%$ (534) and $57.54 \%$ (328) of controlled samples in water supplies systems in Krusevac, Nis and Vranje, respectively. Microbiological analysis of drinking water samples in water supply systems in the study period is shown in Table 10.

Table 10 Microbiological analysis of drinking water samples (2011-2015)

\begin{tabular}{lcccr}
\hline \multirow{2}{*}{ Water supply system } & $\begin{array}{c}\text { The total number } \\
\text { of microbiological } \\
\text { samples }\end{array}$ & $\begin{array}{c}\text { The total number } \\
\text { of microbiological } \\
\text { correct samples }\end{array}$ & $\begin{array}{c}\text { The total number } \\
\text { of microbiological } \\
\text { incorrect samples }\end{array}$ \\
\hline Kruševac & Number of samples (\%) & $570(100 \%)$ & $559(98,07 \%)$ & $11(1.93 \%)$ \\
Niš & Number of samples (\%) & $570(100 \%)$ & $565(99.12 \%)$ & $5(0.88 \%)$ \\
Vranje & Number of samples (\%) & $570(100 \%)$ & $547(95.96 \%)$ & $23(4.03 \%)$ \\
\hline
\end{tabular}


Microbiological correctness of drinking water samples was identified in $98.07 \%$ (559), $99.12 \%$ (565) and $95.96 \%$ (547) of controlled samples in water supply systems in Krusevac, Nis and Vranje, respectively. The causes of physical-chemical incorrectness of water in the control water supply systems in the study period are shown in Table 11.

Table 11 Frequency and percentage of samples having values of parameters outside the permissible levels, causing physical-chemical incorrectness of drinking water (2011-2015)

\begin{tabular}{|c|c|c|c|c|c|c|c|c|}
\hline \multirow{3}{*}{$\begin{array}{l}\text { Water } \\
\text { supply } \\
\text { system }\end{array}$} & \multicolumn{6}{|c|}{ The name of the indicator ${ }^{*}$} & \multirow{2}{*}{\multicolumn{2}{|c|}{$\begin{array}{l}\text { The total number of } \\
\text { incorrect samples }\end{array}$}} \\
\hline & \multicolumn{2}{|c|}{$C_{\mathrm{NH}^{+}}{ }^{+}\left(\mathrm{mg} \mathrm{dm}^{-3}\right)$} & \multicolumn{2}{|c|}{$\mathrm{C}_{\mathrm{KMnO} 4}\left(\mathrm{mg} \mathrm{dm}^{-3}\right)$} & \multicolumn{2}{|l|}{$\mathrm{pH}$} & & \\
\hline & $\begin{array}{l}\text { Number of } \\
\text { samples }\end{array}$ & $\%$ & $\begin{array}{l}\text { Number of } \\
\text { samples }\end{array}$ & $\%$ & $\begin{array}{l}\text { Number of } \\
\text { samples }\end{array}$ & $\%$ & $\begin{array}{c}\text { Number of } \\
\text { samples }\end{array}$ & $\%$ \\
\hline Kruševac & - & - & 221 & 38.77 & 34 & 5.96 & 247 & 43.33 \\
\hline Niš & - & - & 29 & 5.09 & 7 & 1.23 & 36 & 6.32 \\
\hline Vranje & 87 & 15.26 & 79 & 13.86 & 171 & 30.00 & 242 & 42.46 \\
\hline
\end{tabular}

* The same sample may be incorrect due to the presence of multiple indicators of incorrectness.

The results of the analysis of water quality parameters during the study period from 2011 to 2015 showed that the most frequent causes of physical-chemical incorrectness are high concentration of $\mathrm{NH}_{4}{ }^{+}, \mathrm{KMnO}_{4}$ consumption and low $\mathrm{pH}$ levels. In the water supply system in Krusevac, out of a total number of samples (247) or $43.33 \%$, even 221 samples or $38.77 \%$ are contaminated due to $\mathrm{KMnO}_{4}$ consumption, while 34 samples or $5.96 \%$ are contaminated due to their $\mathrm{pH}$. Out of a total number of contaminated samples (36) or 6.32 $\%$ in the water supply system in Nis, 29 samples or $5.09 \%$ were harmful due to $\mathrm{KMnO}_{4}$ consumption and 7 or $1.23 \%$ of samples due to their $\mathrm{pH}$. In the water supply system in Vranje, out of a total number of samples (242) or $42.46 \%, 87$ samples or $15.26 \%$ were risky due to concentration of $\mathrm{NH}_{4}^{+}, 79$ or $13.86 \%$ due to $\mathrm{KMnO}_{4}$ consumption, and 171 samples or $30.00 \%$ due to $\mathrm{pH}$. The causes of microbiological incorrectness of water in the reference water supply systems in the examined period are shown in Table 12.

Table 12 Frequency and percentage of samples having concentrations of bacteria outside the permissible levels, causing microbiological incorrectness of drinking water (2011-2015)

\begin{tabular}{|c|c|c|c|c|c|c|c|c|}
\hline \multirow{3}{*}{$\begin{array}{l}\text { Water } \\
\text { supply } \\
\text { system }\end{array}$} & \multicolumn{6}{|c|}{ The name of the indicator * } & \multicolumn{2}{|c|}{$\begin{array}{c}\text { The total number of } \\
\text { incorrect samples }\end{array}$} \\
\hline & \multicolumn{2}{|c|}{$\begin{array}{l}\text { The total number of } \\
\text { aerobic mesophilic } \\
\text { bacteria in (per) } 1 \mathrm{ml} \\
\left(37^{\circ} \mathrm{C} 48 \mathrm{~h}\right)\end{array}$} & \multicolumn{2}{|c|}{$\begin{array}{l}\text { The total } \\
\text { coliform bacteria } \\
\text { in (per) } 100 \mathrm{ml} \\
\left(37^{\circ} \mathrm{C} 24-48 \mathrm{~h}\right)\end{array}$} & \multicolumn{2}{|c|}{$\begin{array}{c}\text { Fecal } \\
\text { coliform } \\
\text { bacteria } \\
\left(44^{\circ} \mathrm{C} 24-48 \mathrm{~h}\right) \\
\end{array}$} & & \\
\hline & $\begin{array}{c}\text { Number of } \\
\text { samples }\end{array}$ & $\%$ & $\begin{array}{c}\text { Number of } \\
\text { samples }\end{array}$ & $\%$ & $\begin{array}{c}\text { Number of } \\
\text { samples }\end{array}$ & $\%$ & $\begin{array}{c}\text { Number of } \\
\text { samples }\end{array}$ & $\%$ \\
\hline Kruševac & 9 & 1.58 & 2 & 0.35 & 1 & 0.18 & 11 & 1.93 \\
\hline Niš & 5 & 0.88 & 0 & 0.00 & 0 & 0.00 & 5 & 0.88 \\
\hline Vranje & 16 & 2.81 & 7 & 1.23 & 3 & 0.53 & 23 & 4.03 \\
\hline
\end{tabular}

* The same sample may be incorrect due to the presence of multiple indicators of incorrectness.

The results of microbiological testing of drinking water samples from the control water supply systems in the examined period indicate incorrectness in 1.93 to $4.03 \%$ of samples. Microbiological contamination revealed the increased number of aerobic mesophilic bacteria per $1 \mathrm{ml}$ in all control water supply systems $(1.58 \%$ (9 samples) in 
Krusevac, $0.88 \%$ (5 samples) in Nis and $2.81 \%$ (16 samples) in Vranje ), whereas total coliform bacteria per $100 \mathrm{ml}(0.35 \%$ (2 samples) and $1.23 \%$ (7 samples) and fecal coliform bacteria, Escherichia coli and Enterococcus faecalis ( $0.18 \%$ (1 sample) and $0.53 \%$ ( 3 samples), were found in the water supply systems in Krusevac and Vranje, respectively. The causes of microbiological contamination in $1.93 \%$ (11) $0.88 \%$ (5) and $4.03 \%$ (23) of the samples of drinking water from water supply systems in Krusevac, Nis and Vranje, respectively, were an increased number of aerobic mesophilic and coliform microorganisms. The concentration of parameters of physical-chemical insecurity of water in all examined water supply systems is shown in Figures 2-6.
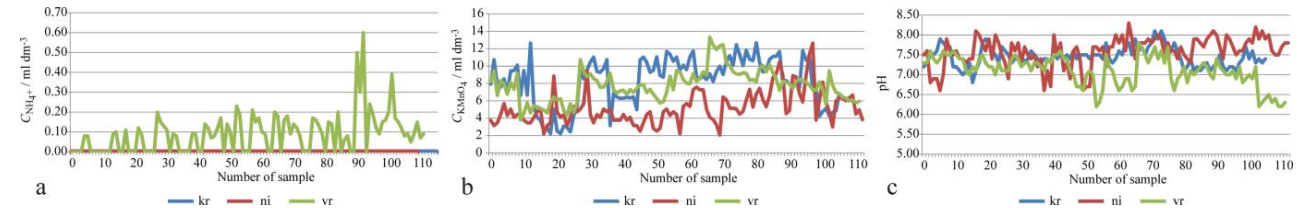

Fig. 2 The concentration of parameters of physical-chemical water insecurity in the examined water supply systems in $2011\left(\mathrm{a}-\mathrm{CNH}^{+}, \mathrm{b}-\mathrm{C}_{\mathrm{KMnO} 4}, \mathrm{c}-\mathrm{pH}\right)$
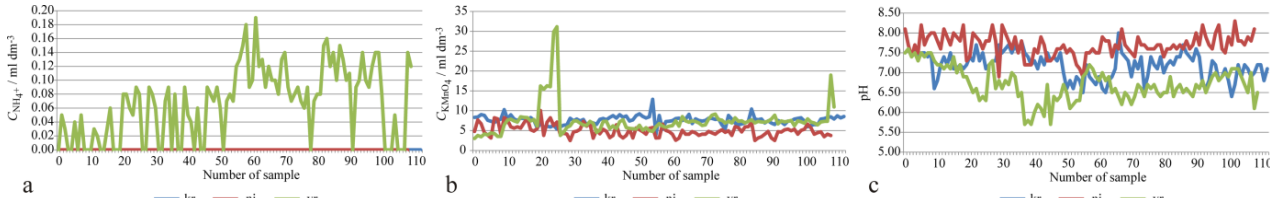

Fig. 3 The concentration of parameters of physical-chemical water insecurity in the examined water supply systems in $2012\left(\mathrm{a}-C_{\mathrm{NH}_{4}}{ }^{+}, \mathrm{b}-\mathrm{C}_{\mathrm{KMnO} 4}, \mathrm{c}-\mathrm{pH}\right)$
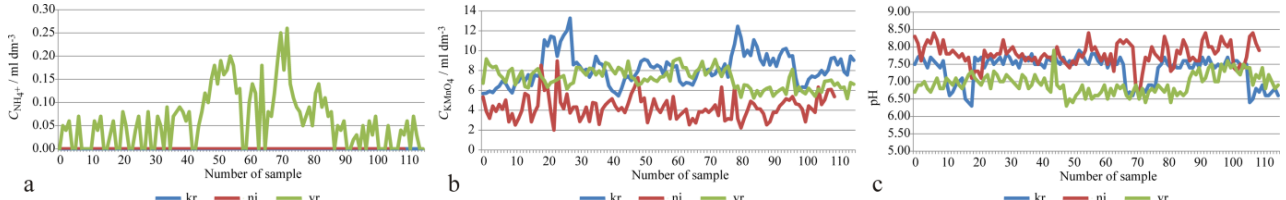

Fig. 4 The concentration of parameters of physical-chemical water insecurity in the examined water supply systems in $2013\left(\mathrm{a}-\mathrm{C}_{\mathrm{NH} 4}{ }^{+}, \mathrm{b}-\mathrm{C}_{\mathrm{KMnO} 4}, \mathrm{c}-\mathrm{pH}\right)$
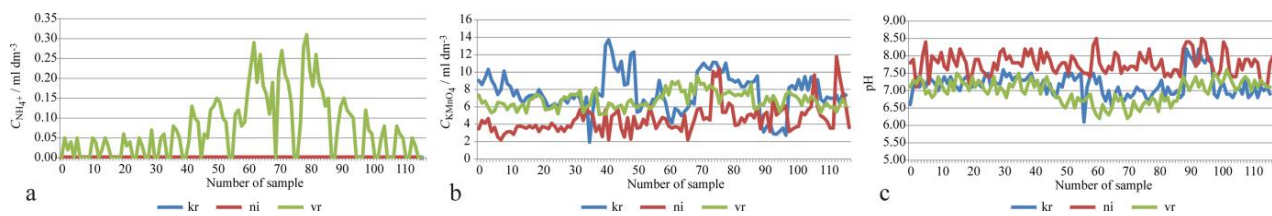

Fig. 5 The concentration of parameters of physical-chemical water insecurity in the examined water supply systems in $2014\left(\mathrm{a}-\mathrm{C}_{\mathrm{NH} 4}{ }^{+}, \mathrm{b}-\mathrm{C}_{\mathrm{KMnO} 4}, \mathrm{c}-\mathrm{pH}\right)$ 

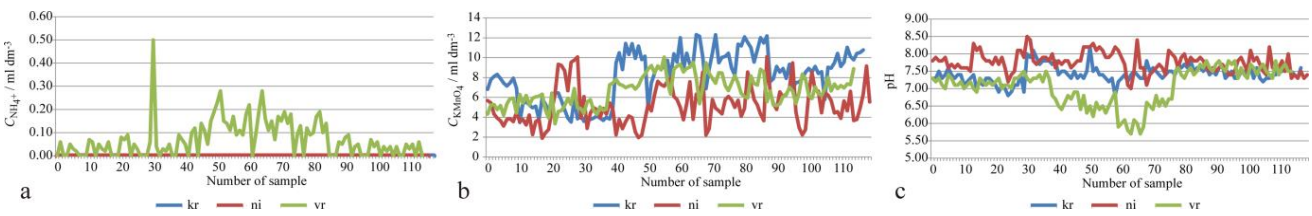

Fig. 6 The concentration of parameters of physical-chemical water insecurity in the examined water supply systems in $2015\left(\mathrm{a}-\mathrm{C}_{\mathrm{NH}_{4}}{ }^{+}, \mathrm{b}-\mathrm{C}_{\mathrm{KMnO}}, \mathrm{c}-\mathrm{pH}\right)$

Pearson correlation coefficient was used to assess the correlation between $\mathrm{NH}_{4}{ }^{+}$ concentration and the presence of bacteria in drinking water samples in the reference water supply systems. The correlation between $\mathrm{NH}_{4}{ }^{+}$concentration and the presence of bacteria in drinking water samples in the control water supply systems is shown in Table 13.

Table 13 The correlation between $\mathrm{NH}_{4}{ }^{+}$concentration and the presence of bacteria in drinking water samples (2011 - 2015)

\begin{tabular}{cccc}
\hline Testing year & $\mathrm{N}$ & $\mathrm{R}$ & $\mathrm{p}^{*}$ \\
\hline 2011 & 112 & 0.042 & 0.661 \\
2012 & 110 & 0.178 & 0.063 \\
2013 & 116 & 0.151 & 0.105 \\
2014 & 117 & 0.079 & 0.398 \\
2015 & 115 & - & - \\
\hline $2011-2015$ & 570 & 0.090 & 0.032 \\
\hline
\end{tabular}

$\mathrm{N}$ - total number of samples; $\mathrm{r}$ - correlation coefficient; $\mathrm{p}$ - statistical significance.

* Statistical significance at the 0.01 level

Pearson correlation coefficient discovered that there was no statistically significant correlation between $\mathrm{NH}_{4}{ }^{+}$concentration and the presence of bacteria in drinking water samples, according to the year of study. However, there was a statistically significant correlation in the whole sample in the 2011-2015 period. The value of the correlation coefficient is 0.09 , which suggests a low correlation between $\mathrm{NH}_{4}{ }^{+}$concentration and the presence of bacteria in samples of drinking water, with a 0.01 level of statistical significance.

In the study period, there were statistically significant differences between the examined water supply systems in terms of the average concentrations of all examined parameters of drinking water quality. Individual differences in mean concentrations of the observed parameters of drinking water quality were examined by post hoc LSD tests and summarized in Table 14.

The highest average $\mathrm{pH}$ values were determined in Nis, whereas the lowest were found in Vranje. Based on the results of the LSD test, it was discovered that there was a statistically significant difference in $\mathrm{pH}$ values between the examined water supply systems in the 2011-2015 period.

Mutual comparison of average concentrations of $\mathrm{NH}_{4}{ }^{+}$ions in the examined water supply systems showed that Vranje significantly differed from Nis and Krusevac, while there was no statistically significant difference between Nis and Krusevac in 2011-2015 period. 
Table 14 The significance of LSD tests for mutual comparisons of average values of parameters between water supply systems

\begin{tabular}{ccccccc}
\hline $\begin{array}{c}\text { Testing } \\
\text { year }\end{array}$ & $\begin{array}{c}\text { Water supply } \\
\text { system }\end{array}$ & $\begin{array}{c}\text { Significance } \\
\text { for } \mathrm{NH}_{4}{ }^{+}\end{array}$ & $\begin{array}{c}\text { Significance } \\
\text { for KMnO }\end{array}$ & $\begin{array}{c}\text { Significance } \\
\text { for NO }{ }^{-}\end{array}$ & $\begin{array}{c}\text { Significance } \\
\text { for pH }\end{array}$ & $\begin{array}{c}\text { Significance } \\
\text { for electrical } \\
\text { conductivity }\end{array}$ \\
\hline \multirow{2}{*}{2011} & Kruševac-Niš & 1.000 & 0.000 & 0.183 & 0.005 & 0.000 \\
& Niš-Vranje & 0.000 & 0.000 & 0.000 & 0.000 & 0.000 \\
& Vranje-Kruševac & 0.000 & 0.090 & 0.000 & 0.000 & 0.000 \\
\hline \multirow{2}{*}{2012} & Kruševac-Niš & 1.000 & 0.000 & 0.033 & 0.000 & 0.000 \\
& Niš-Vranje & 0.000 & 0.000 & 0.000 & 0.000 & 0.000 \\
& Vranje-Kruševac & 0.000 & 0.811 & 0.000 & 0.000 & 0.000 \\
\hline \multirow{2}{*}{2013} & Kruševac-Niš & 1.000 & 0.000 & 0.960 & 0.000 & 0.000 \\
& Niš-Vranje & 0.000 & 0.000 & 0.000 & 0.000 & 0.000 \\
& Vranje-Kruševac & 0.000 & 0.000 & 0.000 & 0.000 & 0.000 \\
\hline \multirow{2}{*}{2015} & Kruševac-Niš & 1.000 & 0.000 & 0.000 & 0.000 & 0.000 \\
& Niš-Vranje & 0.000 & 0.000 & 0.000 & 0.000 & 0.000 \\
& Vranje-Kruševac & 0.000 & 0.000 & 0.000 & 0.000 & 0.000 \\
\hline & Kruševac-Niš & 1.000 & 0.000 & 0.056 & 0.000 & 0.000 \\
\hline & Niš-Vranje & 0.000 & 0.000 & 0.000 & 0.000 & 0.000 \\
\hline
\end{tabular}

The highest mean concentration of $\mathrm{NO}_{3}{ }^{-}$was discovered in Nis, and the lowest in Vranje in 2011, 2013 and 2015. There were no statistically significant differences between Nis and Krusevac, whereas the concentration of $\mathrm{NO}_{3}{ }^{-}$in Vranje significantly differed from its concentration in the other two cities. The highest mean concentration of $\mathrm{NO}_{3}{ }^{-}$was found in Krusevac, while the lowest was discovered in 2012 and 2014. The analysis of the results of the LSD test can prove that there is a significant difference between the reference water supply systems.

The statistical analysis showed that Nis significantly differed in terms of the average values of $\mathrm{KMnO}_{4}$ consumption from Krusevac and Vranje, while there was no significant difference between Krusevac and Vranje in 2011 and 2012. Also, the results of the LSD test discovered that there was a significant difference between the examined systems in terms of $\mathrm{KMnO}_{4}$ consumption in the 2011-2015 period.

In the analyzed period, from 2011 to 2015, the highest average value of electrical conductivity was noticed in Nis, and the lowest in Vranje. Based on the results of the LSD test, it was found that there was a significant difference between the examined water supply systems.

\section{DISCUSSION}

ANOVA tests showed that there were statistically significant differences in all examined parameters between the analyzed water supply systems, except for the concentration of $\mathrm{NO}_{2}{ }^{-}$, which was not found in the samples.

The results of rotated Principal Component Analysis show that that there is a strong correlation between $\mathrm{AS}_{\mathrm{NO} 3}$ and $\mathrm{pH}$, and $\mathrm{AS}_{\mathrm{KMNO} 4}$ (i.e., if $\mathrm{AS}_{\mathrm{NO} 3}$ and $\mathrm{pH}$ are higher, the values of $\mathrm{AS}_{\mathrm{KMNO4}}$ will be lower), which can be used in monitoring the quality of the water in the investigated cities (Vranje, Nis, Krusevac), reducing the number of variables to be 
determined. On the other hand, the results of Agglomerative Hierarchical Clustering (AHC) show that water in each of these cities has distinguishing qualities, whereas water in Vranje shows particularly prominent features

Health safety (physical-chemical and microbiological safety) was investigated in $\mathbf{5 4 . 7 4}$ $\%$ (312), $92.81 \%$ (529) and $53.51 \%$ (305) of controlled samples of water supply systems in Krusevac, Nis and Vranje, respectively.

Physical-chemical safety of drinking water samples was confirmed in $56.67 \%$ (323), $93.68 \%(534)$ and $57.54 \%$ (328) of controlled samples in water supply systems in Krusevac, Nis and Vranje, respectively.

Microbiological safety of drinking water samples was identified in $98.07 \%$ (559), 99.12 $\%$ (565) and $95.96 \%$ (547) of controlled samples of water supplies systems in Krusevac, Nis and Vranje, respectively. E. coli or enterococci of fecal origin were found in only one sample $(0.18 \%)$ in the water supply system in Krusevac and 3 samples $(0.53 \%)$ in Vranje in the 2011-2015 period.

The research carried out by Mitić-Stojanović and Cibulić in the water supply system in Vranje in 2001 discovered that concentration of $\mathrm{NH}_{4}{ }^{+}$was the cause of drinking water contamination in $88.83 \%$, out of 188 samples, which was considerably more in comparison to the results obtained in the 2011-2015 research (in $2011-25 \%$, in $2012-5.45 \%$, in 2013 $10.34 \%$, in $2014-18.80 \%$ and $2015-16.52 \%$ ) [13]. The reason for a significantly lower percentage of contaminated samples due to concentration of $\mathrm{NH}_{4}{ }^{+}$was the introduction of a new water supply system from the reservoir since 2006.

Additional exposure to ammonia from water in the range from 0.014 to $0.14 \mathrm{mg} \mathrm{kg}^{-1}$ of body weight per day is negligible and does not represent a risk to human health, even to vulnerable groups [14].

In 2001, there was $31.38 \%$ of contaminated water samples due to $\mathrm{pH}$ value, out of 188 samples tested, which was consistent with the results obtained in this study, where the average value of contaminated samples was $30.00 \%$. Microbiological contamination was identified in 3.93\% of 1679 samples tested in 2001, whereas the 2011-2015 research discovered $4.03 \%$ microbiologically contaminated samples out of 570 samples.

High concentrations of $\mathrm{NH}_{4}{ }^{+}$were found in $88 \%$ of samples in 2001, and it was significantly reduced in the 2011-2015 period, which was defined in this study, while microbiological contamination of water samples remained unchanged. On this basis, it can be concluded that the concentration of ammonia was not correlated with microbiological insecurity of drinking water, which is consistent with the results of this research. Also, a recent study has found that there were no statistically significant differences between the physical-chemical parameters and the total number of coliform group of bacteria, which is consistent with the results of this research [15].

The analysis of the qualitative impact of drinking water on human health was performed on the basis of risk indicators (physical-chemical and microbiological) of water quality and their corresponding percentage of incorrectness.

Based on the indicators of drinking water quality in terms of microbiological insecurity, the risk of negative effects of drinking water on human health was minor in the examined water systems in Krusevac and Vranje, while this risk was insignificant in the water supply system in Nis.

According to the indicators of drinking water quality in terms of physical-chemical insecurity, it was discovered that the risk of adverse effects of drinking water on human health was very high in the water systems in Krusevac and Vranje, while it is partially 
acceptable in the water supply system in Nis; therefore, it is necessary to observe their quality constantly and systematically with suitable monitoring [4].

The quality of available water intended for water supply depends on natural factors, such as the geomorphological structure of the terrain, climate conditions, but also on human activity, since a lot of products of human activities get into the water.

The concentrations of $\mathrm{NH}_{4}{ }^{+}$ions above the MPC and low $\mathrm{pH}$ levels in the water supply system in Vranje are closely linked with the inclusion of additional water sources in the form of wells spread along the river. The results obtained in the 2011-2015 period show that the water in that area was microbiologically correct in $95.96 \%$ of the samples, even though it contained high concentrations of ammonia in $15.26 \%$ of the samples, concerning the limits defined by the current Drinking Water Regulations. Relying only on the city's main water source, the presence of ammonia in concentrations above the MPC would be avoided and normal $\mathrm{pH}$ values would be obtained.

The increased $\mathrm{KMnO}_{4}$ consumption and low pH levels in the water supply system in the town of Krusevac indicate the increased presence of organic matter in these waters in "the flourishing period of the lake". The cause of this occasional phenomenon is an inadequate process of raw water purification and an unregulated zone of a strict regime at the source as well as a possibility of insecurity of industrial and fecal wastewater in the limit zone.

In the research period, there were statistically significant differences between the examined water supply systems in terms of average concentrations of physical-chemical parameters of drinking water quality.

The microbiological analysis of drinking water showed no outbreaks of disease caused by fecal contamination of water during the study period.

\section{CONCLUSION}

In three selected municipalities of Serbia, drinking water does not show satisfactory quality in terms of the presence of the tested pollutants. Also, there were statistically significant differences between the examined water supply systems in terms of average concentrations of physical-chemical parameters of drinking water quality. Constant and systematic monitoring of investigated supply systems is further necessary. Also, reforms in the water industry and water security system are required, especially in selected regions.

Acknowledgement: This research was financially supported by the Ministry of Education, Science and Technological Development of the Republic of Serbia, contract no. 451-03-9/2021-14/200148.

\section{REFERENCES}

1. Working group on Water Resources (2007). National Strategy for Sustainable Use of Natural Resources of the Republic of Serbia, Ministry of Agriculture, Forestry and Water Management/Directorate for Water.

2. Regulation on the Hygienic Acceptability of Potable Water, Official gazette of FRY, 1998, number 42/98.

3. Regulations on the Sampling Process and Methods of Drinking Water Analyses in Laboratories, Official gazette of FRY, 1987, number 33/87.

4. Regulations on the National List of Environmental Protection Indicators, Official gazette of RS, 2011, number 37/2011. 
5. Microbial risk assessment (MRA) tool. Urban Water [report] (2005). Gothenburg: Sweden; Chalmers University of Technology.

6. Cabral JP (2010). Water microbiology. Bacterial pathogens and water. International Journal of Environmental Research and Public Health, 7(10), 3657-703. http://dx.doi.org/10.3390/ijerph7103657

7. Rompré A, Servais P, Baudart J, de Roubin MR, Laurent P (2002). Detection and enumeration of coliforms in drinking water: current methods and emerging approaches. Journal of Microbiological Methods, 49(1), 31-54. http://dx.doi.org/10.1016/S0167-7012(01)00351-7

8. Edberg SC, Rice EW, Karlin RJ, Allen MJ (2000). Escherichia coli: The best biological drinking water indicator for public health protection. Symposium series (Society for Applied Microbiology), (29), 106S-116S. http://dx.doi.org/10.1111/j.1365-2672.2000.tb05338.x

9. Ashbolt NJ, Grabow WOK, Snozzi M (2001). Indicators of microbial water quality. In: Fewtrell L, Bartram J, editors. Water Quality: Guidelines, Standards and Health. Risk assessment and management for water-related infectious disease. London: IWA Press, 289-316.

10. Soller J, Embrey M, Tuhela L, Ichida A, Rosen J (2010). Risk-based evaluation of Escherichia coli monitoring data from undisinfected drinking water. The Journal of Environmental Management, 91(11), 2329-35. http://dx.doi.org/10.1016/j.jenvman.2010.06.017

11. Pinto B, Pierotti R, Canale G, Reali D (1999). Characterization of faecal streptococci as indicators of faecal pollution and distribution in the environment. Letters in Applied Microbiology, 29(4), 258-263. http://dx.doi.org/10.1046/j.1472-765X.1999.00633.x

12. Armitage P, Berry G (2000). Statistical methods in medical research. Oxford: Blackwell Science.

13. Mitić-Stojanović DL, Cibulić V (2011). Water supply Vranje, then and now. In: Đukić A, editor. Proceedings of the 40th Conference on Current Problems of Water Use and Protection ,Water 2011”, jun 7 - 9, Zlatibor, Serbia, Belgrade: Serbia, 425-30.

14. Statement of EFSA (2012). Health risk of ammonium released from water filters, European Food Safety Authority EFSA Journal. 10(10), 2918

15. Aryal J, Gautam B, Sapkota N (2012). Drinking water quality assessment. Journal of Nepal Health Research Council, 10(22): 192-6.

\section{POTENCIJALNI UTICAJ IZVORA VODE ZA PIĆE NA ZDRAVLJE LJUDI: STUDIJA SLUČAJA IZ SRBIJE}

Kvalitet vode za piće ima direktan uticaj na zdravlje stanovništva i glavni je pokazatelj ekološke i higijenske ispravnosti. Cilj ove studije bio je da istraži kvalitet vode za piće iz tri sistema vodosnabdevanja u Srbiji.

Retrospektivna deskriptivna studija urađena je za period između 2011. i 2015 godine. Prikupljeni su podaci iz kontrolnih sistema vodosnabdevanja u tri grada i testirani uzorci u skladu sa Uredbom o higijenskoj prihvatljivosti vode za piće. Analizirani su sledeći pokazatelji ispravnosti vode: amonijak, nitrati, nitriti, potrošnja kalijum-permanganata, sadržaj organske materije, $\mathrm{pH} i$ elektroprovodljivost. Mikrobiološki kvalitet utvrđen je analizom pokazatelja fekalne kontaminacije, Escherichia coli, Enterococci i Salmonellae, primenom metode membranske filtracije.

Najčešći parametri fizičko-hemijske neispravnosti vode bili su visoka koncentracija amonijaka, niži nivo pH i povećana potrošnja kalijum-permanganata. Najčešći otkriveni mikrobi su aerobne mezofilne bakterije koje sa aspekta zaštite zdravlja nisu značajne.

Ovi rezultati su pokazali da voda za piće, može predstavljati potencijalni rizik za lokalne potrošače.

Ključne reči: voda za piće, kvalitet, zdravstveni aspekt. 